\title{
Managing Gallstone during Pregnancy
}

\section{Tatalaksana Batu Empedu pada Kehamilan}

\author{
Toar JM Lalisang, Fransisca J Siahaya \\ Division of Digestive Surgery \\ Department of Surgery/ \\ Dr. Cipto Mangunkusumo Hospital \\ Jakarta
}

\begin{abstract}
Transient physiological changes in the biliary system during pregnancy increased the risk of gallbladder diseases. Nonoperative management of symptomatic cholelithiasis increases the risk of complications of biliary lithiasis, such as cholecystitis and empyema, while obstruction common bile duct stones with or without cholangitis and biliary pancreatitis raise maternal mortality. Delay in definitive surgical treatment of biliary diseases during pregnancy increases the likelihood acute biliary pancreatitis which impact on preterm delivery until fetal lost. Laparoscopic cholesystectomy during pregnancy has advantages for the mother in that it speeds up her recovery, giving her less pain and facilitated natural birth without a cesarean section. On the fetus side, laparoscopic cholecystectomy is safe since it does not induce preterm delivery or abortion. Identification of gallbladder stone during pregnancy warrant a preventive laparoscopic cholesystectomy or endoscopic CBD exploration, both of which promise good outcomes.

[Indones J Obstet Gynecol 2013; 1-4: 219-21]
\end{abstract}

Keywords: adult choledochal cyst, biliary cyst, biliary dilatation, mixed type

\begin{abstract}
Abstrak
Perubahan fisiologi ectiosistem empedu selama kehamilan meningkatkan risiko terjadinya penyakit saluran empedu. Tatalaksana non operatif terhadap kolelitiasis simptomatik meningkatkan risiko terjadinya komplikasi seperti kolesistitis dan empiema, sementara sumbatan common bile duct dengan atau tanpa kolangitis dan pankreatitis meningkatkan mortalitas ibu. Tertundanya tatalaksana pada pasien hamil dengan penyakit empedu meningkatkan kemungkinan terjadinya pankreatitis bilier akut yang dapat menyebabkan kelahiran prematur hingga kematian bayi. Kolesistektomi laparoskopik pada pasien hamil memberikan waktu pulih yang lebih cepat, nyeri yang minimal dan memungkinkan ibu untuk bersalin secara normal tanpa operasi seksio sesarea. Kolesistektomi laparoskopik juga aman bagi bayi karena tidak merangsang kelahiran preterm atau aborsi. Ditemukannya batu empedu dalam kehamilan menjadi indikasi dilakukannya kolesistektomi laparoskopik atau eksplorasi duktus bilier komunis secara endoskopik, di mana kedua prosedur menjanjikan hasil yang baik.

[Maj Obstet Ginekol Indones 2013; 1-4: 219-21]
\end{abstract}

Kata kunci: dilatasi empedu, kista empedu, kista koledokus dewasa, tipe campuran

Correspondence: Fransisca J Siahaya. Division of Digestive Surgery, Department of Surgery/Dr. Cipto Mangunkusumo Hospital,

\section{INTRODUCTION}

Nonobstetric general surgery procedures are required in approximately 1 in 635 pregnancies. $^{1}$ Common abdominal emergencies during pregnancy include cholecystitis, acute appendicitis, and intestinal obstruction. ${ }^{2}$ Physiologic changes during pregnancy increases the risk of biliary sludge and stones formation. ${ }^{3-5}$ However, pregnancy does not seem to increase the likelihood of their complications. The incidence of gallstone-related diseases complicating pregnancy is $0.05 \%$ to $0.8 \% .^{2}$ Cholecystectomy is required in approximately $45 \%$ of pregnant patients who present with symptomatic cholelithiasis with a $5 \%$ rate of fetal loss associated with open cholecystectomy.This is complicated by a $15 \%$ incidence of maternal mortality and up to a $60 \%$ incidence of fetal loss if the disease progresses to acute biliary pancreatitis. ${ }^{1}$ Therefore, management of these diseases has always been a diagnostic and therapeutic challenge.

Table 1. Risk Factors and Phatogenic Pathway of Billiary Disorder in Pregnancy

\begin{tabular}{ll}
\hline \hline \multicolumn{1}{c}{ Risk Factors } & \multicolumn{1}{c}{ Phatogenic Pathway } \\
\hline Age & Sex steroids \\
Dietary fat & Gall bladder hypomotility \\
Iron supplements & Increased bile acid pool size \\
Previous pregnancies & Larger gallbladder volumes \\
Gall Bledder Diseases history & Incomplete postprandial emptying \\
Body Mass Index & Lithogenic bile \\
Prenatal physical activity & Decreased enterohepatic circulation
\end{tabular}

Prenatal weight gain

Serum cholesterol

Serum leptin 


\section{Conservative vs Surgical Treatment}

Pregnancy remain relative contraindication for laparoscopy procedure due to the risk of spontaneus abortion, prematurity, perinatal and maternal mortality. Reviews supporting the feasibility and safety of laparoscopy procedure were published toward the end of $20^{\text {th }}$ century. These reviews showed that $27 \%$ of patients were failed to response to conservative treatment. ${ }^{2}$ Risks of conservative treatment of cholecystitis include risk to the fetus due to recurrent episodes, other complications of gallstones, and risk of malnutrition caused by lack of oral intake. ${ }^{2}$ Conservative management is also associated with multiple hospitalization (2-6 relapses during pregnancy). ${ }^{2}$ Each subsequent relapse was more severe than the previous one.

Feasibility and safety of the laparoscopy procedure during pregnancy were observed in numerous case reports. These reports then were reviewed and investigators concluded that laparoscopy cholecystectomy was a safe and effective option for complicated and nonresolving biliary disease during pregnancy. $2,4,5$

Despite potential advantages of laparoscopic cholecystectomy in the pregnant patient, include decreased fetal depression due to lessened postoperative narcotic requirements, decreases the chance of incisional hernia, shorter length of hospital stay, and a decreased incidence of thromboembolic events, surgical intervention during pregnancy still results in fetal loss from either spontaneous abortion (especially in the first trimester) or premature labor (especially in the third trimester). Laparoscopy technique, in other hand, also contribute potential risk for fetus and maternal. Pneumoperitonium (ussualy with $\mathrm{CO}_{2}$ ), uterine injury during trochar placement, decreases uterine blood flow were highly concern to caused fetal lost. ${ }^{1-5}$ Certain maneuvers must be routinely adopted in order to enhance operative safety, which will be specifically discussed in the following section.

\section{Management Gallstone during Pregnancy}

The spectrum of gallstone diseases range from biliary colic to life-threatening pancreatitis, therefore management must be tailored to the patient's presentation. Obstetrical consultation should be obtained preoperatively.

\section{Management of Symptomatic Cholelithiasis}

Simptomatic cholelithiasis in pregnant women could bring risk the fetus due to its recurrent episodes. ${ }^{2,3,6}$ Surgery is inevitable in the presence of complications, such as pancreatitis, impending cholangitis, obstructive jaundice and biliary colic unresponsive to medical treatment. Several consideration should be noticed for laparoscopy procedure. Surgical intervention, if necessary, is a safe procedure during all trimesters but is best carried out during the second trimester when fetal risk is at its lowest. ${ }^{1-3,5}$ The historic reasons for carrying out a surgery at this time include the fact that organogenesis is complete and the uterus is not big enough to obliterate the surgical view. Use the left lateral position to minimize aortocaval compression. Open technique (Hasson) should be used to insert the umbilical port. Avoid high intraperitoneal pressures (8-12 $\mathrm{mmHg}$ ) and rapid changes in patient's position. Take care to use electrocautery cautiously and away from uterus. ${ }^{2,3,7}$ Despite all these manuvers, it is very important for the surgeon to be skilled in advanced laparoscopic technique and a strong support structure must be placed to deal with potential complications.

\section{Management of Choledocholithiasis}

Ductal stones may pose a risk to both fetus and mother by causing obstructive jaundice, cholangitis, or pancreatitis. It poses diagnostic as well as therapeutic dilemmas during pregnancy. ERCP, IOC and MRCP as diagnostic and therapeutic modalities are not without risk. ${ }^{1,2,4}$ Until recently ERCP was contraindicated in pregnancy, although there is reports on ERCP during pregnancy that showed no serious harm to mother or fetus. The amount of radiation used during ERCP was 18 to $310 \mathrm{mrad}$, which is lower than the harmful dose of 5 to 10 rad, which is the dose at which fetal damage is known to occur. ${ }^{1-3}$ Literatures also suggested that the procedure should only be performed by an experienced endoscopist, and the fetus should be shielded at all times. ${ }^{2,3}$ Nowadays, laparoscopic bile duct exploration with intraoperative choledochoscope might be the treatment of choice since it do not utilize radiation procedure.

\section{Management of Acute Pancreatitis}

The initial management of acute pancreatitis during pregnancy is similar to the management in the 
general population. The subsequent management of severe acute pancreatitis is less controversial because maternal safety is of paramount importance, and fetal outcome becomes a secondary concern. ${ }^{2}$ However, the treatment of mild to moderate pancreatitis during pregnancy still a controversy. British Society of Gastroenterology guidelines recommended early elective cholecystectomy after index admission.2,3 When cholecystectomy is deferred until after delivery, nearly $60 \%$ of patients develop recurrence during the same pregnancy, which significantly increases morbidity, frequency, and length of hospitalization. ${ }^{2,3}$ There is also an increased risk of fetal loss, prematurity and low birth weight babies.

\section{Conclusion and Recommendation}

Early minimal invasive intervention is the treatment of choice in managing gallstones during pregnancy. Laparoscopic cholecystectomy is superior to non-operative management and it is a safe procedure during all trimesters. ${ }^{2,3,5,7,8}$ Early intervention, on the other hand, might avoid repeated hospitalization and patient's discomfort, but could also result in spontaneous abortion, perinatal mortality, prematurity, maternal morbidity and mortality. It is not the intervention, but the severity of the disease, which is more important in the decision making. Optimizing maternal and fetal outcomes requires the collaboration of surgeons, gastroenterologists, obstetricians, neonatologists, anesthesiologists, insurers, and policymakers. We made several recommendations in managing gallstone during pregnancy. $2,3,5,8$

It may be advisable for women with symptomatic gallstones to undergo cholecystectomy before planning pregnancy, Laparoscopic cholecys- tectomy for symptomatic cholecystitis is a safe procedure during all trimesters, Laparoscopic cholecystectomy in pregnancy should performed in high volume center by a surgeon with advanced laparoscopic skilled, Special procedures and techniques must be routinely adopted to enhance operative safety, Laparoscopic bile duct exploration and intraoperative choledochoscopy are feasible options for managing common bile duct stones, ERCP during pregnancy is accepted as long as the fetus is shielded for protection along the procedure, and Laparoscopic cholecystectomy should be offered to the patients with mild to moderate gallstone pancreatitis according to guidelines for non-pregnant patients.

\section{REFERENCES}

1. Corneille MG, Gallup TM, Bening T et al. The use of laparoscopic surgery in pregnancy: evaluation of safety and efficacy. Am J Surg. 2010; 200: 363-7.

2. Date RS, Kaushal M, Ramesh A. A review of the management of gallstone disease and its complications in pregnancy. Am J Surg. 2008; 196; 599-608.

3. Chiedozi LC, Al Hadi FNH, Salem MM et al. Management of Symptomatic Cholelithiasis in Pregnancy. Ann Saudi Med. 2001; 21(1-2):38-41

4. Kuy SR, Roman SA, Desai R et al. Outcomes Following Cholecystectomy in Pregnant and Nonpregnant Women. J Surg. 2009; 146(2):358-66

5. Luis Tom'as Chiappetta Porras, Eduardo Daniel N'apoli et al. Minimally Invasive Management of Acute Biliary Tract Disease during Pregnancy. HPB surg. 2009.

6. Efthimiadis C, Kosmidis C, Grigoriou M et al. The Role of Laparoscopic Surgery in Pregnant Women with Nonobstetric Acute Abdomen. J Gynecol Surg. 2010; 26(4): 251-3

7. SAGES Guidelines. Surgical Endoscopy Utrasound and Interventional Techniques. 1998; 12: 186-8.

8. Dhupar R, Smaldone GM, Hamad GG et al. Is there a benefit to delaying cholecystectomy for symptomatic gallbladder disease during pregnancy? Surg Endosc. 2010; 24:108-12 